\title{
CZU:631.58:551.5 https://doi.org/10.53040/gppb7.2021.32 \\ VALUE OF QTL ANALYSIS IN PRECISION AGRICULTURE SYSTEM
}

\author{
Chesnokov Yu.V. \\ Agrophysical Research Institute, Saint-Petersburg, Russia \\ e-mail: yuv_chesnokov@agrophys.ru
}

\begin{abstract}
A possible relationship between the approaches of adaptive crop production and precision agriculture to produce environmentally friendly lines and varieties with high adaptive potential and productivity is shown. In recent decades, more and more attention has been paid to technogenic and biological systems of farming, based on the ecologization and biologization of the intensification processes of adaptive crop production. Such approaches are precision agriculture (PA) system and QTL analysis. The use of these approaches allows not only to ensure a sustainable increase in productivity through the combined use of the advantages of precision agriculture and molecular genetic assessment, including the creation of new forms and varieties responsive to agricultural practices of PA, but also to neutralize the negative impact of abiotic and biotic environmental factors limiting the size and quality of the crop as well as plant productivity.
\end{abstract}

Key words: adaptive crop production, precision agriculture, QTL analysis, bread wheat

In accordance with the fundamental principles of adaptive crop production, developed by academician A.A. Zhuchenko [1], the strategy of biological adaptation of cultivated plant species is implemented at different levels of development of living matter (molecular, subcellular, cellular, organ, organismic, population, species, biocenotic, biospheric) and is achieved using different mechanisms (genetic, biochemical, physiological, morphoanatomical) [2], the ultimate goal of which is to ensure a sustainable increase in the size and quality of the crop based on increasing the potential productivity and ecological sustainability of varieties of cultivated crops and agrocenosis.

Modern agriculture is one of the most knowledge-intensive sectors of the economy. In this regard, in recent decades, more and more attention has been paid to the so-called high-precision (precision) agriculture, based on the use of high technologies (telecommunications, information and satellite navigation systems for data collection and processing, etc.). With the help of such a system and special equipment (seeders, fertilizer spreaders, sprayers, combines, etc.), precise sowing of seeds, application of fertilizers, pesticides and biologically active substances is carried out, which gives a great economic and environmental effect. It is obvious that the system of high-precision (precision) agriculture incorporates all the centuries-old and modern experience, including adaptive in time and space, the placement of cultivated plant species and varieties, i.e. the use of systems and developments in adaptive crop production. At the heart of high-precision agriculture and varietal agricultural technology, the most important component of the first, is the adaptive use of natural, biological, technogenic, labor and other resources [1]. It is in the interconnection of the use of technologies and approaches of adaptive crop production and high-precision agriculture that resource efficiency, environmental protection, reliable environmental sustainability and profitability of agricultural production at the present stage of its development can be ensured.

It should be noted that varietal agricultural technology is based on the management of plant modification variability, i.e. is determined by the specificity of the adaptive reactions of each variety (genotype) at different stages of ontogenesis, as well as the nature of the correlations (positive and negative) between the components of potential productivity and ecological stability. In cases of using multi-line and synthetic varieties, as well as mixed crops, it is necessary to assess the influence of agrotechnical methods and on the change in the genotypic structure of the corresponding agrocenoses. As the number of environmental factors, regulated by agrotechnics and agro-technologies, increases, it is necessary to create varieties with a higher level of responsiveness to these factors [3]. Studying the nature of adaptive reactions of different varieties, one should distinguish between the ecovalence of independent and functionally related traits. In this case, the coefficients of variation $\left(\mathrm{C}_{\mathrm{v}}\right)$ and correlation $\left(\mathrm{R}_{\mathrm{P}}\right.$ and $\left.\mathrm{R}_{\mathrm{G}}\right)$ can be used both in breeding and in programming the yields of agricultural plants, including the development of varietal agricultural techniques and agricultural practices [5, $6]$, including the system of precision agriculture. 
It is especially important to develop varietal agrotechnics for agroecologically specialized varieties and hybrids, which differ in narrow limits of adaptation to varying environmental conditions. Moreover, the size and quality of the yield of such varieties varies more strongly not only as a result of weather fluctuations, but also depending on the level of agricultural technology and agricultural practices. This explains the situations when technogenic-intensive varieties are less productive than local varieties in unfavorable soil, climatic and weather conditions, as well as with limited opportunities for optimizing environmental conditions through fertilizers, ameliorants, pesticides, irrigation, etc. Therefore, when developing varietal agricultural techniques and agricultural practices for their use in the system of precision farming for each variety and hybrid, it is important to identify the specifics of the "critical" periods of ontogenesis, as well as the phase of the greatest responsiveness to regulated environmental factors. For example, the mechanisms of increasing plant tolerance are often associated with growth retardation and even its complete cessation $[1,6]$, therefore, plant growth management is one of the main tasks of varietal agricultural technology and therefore the system of precision agriculture as well. It is precisely by the methods of agricultural technology that it is possible to significantly weaken the daily fluctuations of growth processes and, due to this, the size and quality of the crop, which, in fact, is observed when using agricultural methods of the precision agriculture system $[8,9]$. It is also important to take into account that many agricultural practices and agricultural techniques, as an integral part of precision agriculture, aimed at enhancing growth processes (application of increased doses of nitrogen fertilizers, ameliorants, irrigation, etc.), can contribute to a decrease in plant resistance to the action of abiotic and biotic stressors. Therefore, at the same time, the features of the dynamics of growth and development of plants (variety, genotype), as well as architectonics, are used as the most important component of varietal agrotechnics of precision agriculture in the design of adaptive agroecosystems and agricultural landscapes. This approach will allow not only to significantly increase the optimization, but also the regulatory role of technogenic factors and the system of precision agriculture as a whole.

At the same time, it should be noted with certainty that attempts to reduce high-precision agriculture only to the use of technical means, including new information systems, are untenable in principle. First of all, high-precision agriculture is an adaptive-differentiated use of all the most important natural, biological and man-made factors that determine the value, quality and timing of crop production. Therefore, high-precision agriculture involves the use of information technology, data of remote active and passive sensing, robotic devices, special agricultural equipment with the obligatory monitoring of the growing conditions of each crop, each variety of each plant species. In this regard, the adaptive-differentiated use of chemical-technogenic factors of intensification of crop production acquires special significance and meaning, providing a differentiated and at the same time integrated process of managing the growth and development of plants in accordance with their biological needs in specific ecological-geographical and soil-climatic conditions.

To date, numerous data have been obtained indicating the specificity of the reaction of various varieties (genotypes) to the action of environmental factors. So in the works of Lvov (1930), Pryanishnikov (1955), Harvey (1939, 1941, 1956), Butkevich (1947), Brezhnev (1950), Skazkin (1961), Balashov (1065), Godunova (1967) and others show the specificity responsiveness of varieties and hybrids of different crops to irrigation and fertilization (doses of N, P, K and their ratio, timing of application, etc.) (cited from [5]). For example, the varietal specificity of tomato responsiveness to changes in environmental conditions manifested itself in terms of both yield and average fruit weight, the ability to set fruits in high and low temperatures, the content of dry substances, sugars and vitamin $\mathrm{C}$ in fruits, etc. $[5,6]$. If tomato varieties Sibirskiy early ripening and Gruntovy gribovskiy turned out to be very responsive to micronutrient fertilizers (yield increase was 59-150\%), then in Sibirskiy shtambovy variety under the influence of the same factors the yield changed by only $3-23 \%$. The differences between different varieties of beans in the efficiency of using absorbed nutrients reached $44 \%$ for nitrogen, $72 \%$ for phosphorus, and $100 \%$ for potassium. In favorable years, the productivity of the barley variety Ganna Loosfdorfskaya increased by 2-2.5 times due to the NPK application, while in the variety Yuzhny only by $15 \%[1,3,5]$. The influence of nitrogen fertilizers on the size and quality of the yield of different varieties of winter wheat was demonstrated in the experiments of Sandukhadze and colleagues [7].

Today, the main agrotechnical measure, during which the most effective use of agricultural technologies of precision agriculture is carried out, is the introduction of mineral fertilizers and agrochemicals. This is due to the following factors: 
- a high degree of anthropogenic impact on the environment of agrochemicals in the case of their excessive application in certain areas of the field (excluded with differential application);

- the high cost of agrochemicals (with differentiated application, it can be significantly reduced);

- developed technical base of agricultural machinery, primarily imported for the differentiated application of liquid and solid mineral fertilizers and agrochemicals;

- the emergence on the market of software, on-board computers and navigation aids (GPS / GLONASS receivers), which allow to create spatially oriented field maps with high accuracy and control the differentiated application of fertilizers and agrochemicals in real time;

- the appearance on the market of sensors that determine the nutritional deficit of agricultural crops, and software for the formation and implementation of agricultural practices in the system of precision farming.

However, all of the above requires the involvement and close attention in relation to the creation of genotypes, lines and varieties that are responsive to the proposed and ongoing agricultural practices, and purposefully created for their application in the system of precision farming.

That is why breeding and agro-technical programs aimed at increasing the potential productivity and ecological sustainability of agroecosystems should be integrated. In this regard, according to academician A.A. Zhuchenko [3], the most effective, especially in terms of resource efficiency and environmental safety, is the genetic improvement of plants, i.e. creating a situation when, according to N.I. Vavilov, "the genotype dominates the environment" [cit. according to: 3]. Since a prerequisite for the development and use of varietal agricultural technology in the precision agriculture is knowledge of the variability features of economically valuable traits of each variety under the influence of both regulated and unregulated environmental factors, the development of methods and approaches for the purposeful creation of such varieties. One of the approaches that can be used to achieve these goals is the mapping of chromosome loci responsible for the manifestation of economically valuable traits, including those determining the growth and development of agricultural plants, as well as those associated with the identified loci of reflection indices.

At the Agrophysical Research Institute during 2009-2019 experiments were carried out to identify the number and establish the exact localization of quantitative trait loci (QTL) involved in the physiological and genetic process of the implementation of complex agronomically important traits in spring bread wheat (Triticum aestivum L.) introduction of nitrogen fertilization [4]. The efficiency of assimilation of nitrogen fertilizers is a complex trait controlled by many genes, which depends on the genotypeenvironment interaction. Determination of the effect of nitrogen fertilizers on various genotypes is one of the most promising approaches for achieving high plant productivity. In order to improve the consumption properties of nitrogen fertilizers, in addition to the conditions and quantities of fertilizers applied, it is necessary to take into account not only the genotype of the crop, but also the effects of the environment, as well as the interaction of these three factors.

Quantitative and qualitative changes of the physiological and biochemical intracellular composition and the internal morphophysiological structure of leaves under adverse conditions and also during plant adaptation to growing conditions are accompanied by changes in their optical characteristics. The direction and the level of such changes characterize the physiological and genetic resistance of plants and allow researchers to study the mechanisms of their response to the action of stress factors. Registration of optical characteristics, such as the diffuse reflectance spectra of laminas represents a noninvasive method and can be performed in both contact or remote modes.

Using the QTL mapping method provides the ability to identify the genetic control of quantitative traits and genes that control complex traits. A variety of QTLs have been identified at low and high doses of nitrogen nutrition under different growing conditions in different crops. However, prior to our study, not a single study was carried out in which the identification of genetic determinants that determine the manifestation of quantitative traits responsible for the absorption and efficiency of nitrogen fertilizers use under controlled conditions of an agroecobiopolygon was carried out. As a result of the studies, it was found that the variation in the manifestation of agronomically significant traits under strictly controlled conditions of the agroecobiopolygon in the same genotypes of the lines of the mapping ITMI population was significant for some parameters of the QTL analysis and depended on whether or not the wheat plants were fed with nitrogen fertilizers [4 ]. Also, for the first time, the QTL mapping of the diffuse reflection 
indices of the leaf blade was carried out, which determine the chlorophyll content, the ratio of carotenoids to chlorophyll, the photochemical activity of the photosynthetic apparatus, the content of anthocyanins, the measure of light scattering by the leaf, as well as the area of the assimilating leaf surface and grain productivity indicators of spring bread conditions of the regulated agroecosystem of the biopolygon in the absence and with the introduction of nitrogen fertilization. Obtained in our study results [4] indicate that the used noninvasive optical methods provide a possibility to evaluate photosynthetic intensity in plants and can be applied for selection of the promising wheat genotypes. These methods can be used in the field, though they are the most efficient under controlled conditions of agroecobiological testing grounds. They provide a high throughput analysis of phenotypical traits as well as the study of relationships between the phenotype and genotype and their variability during realization of the evolutionary adaptive and physiology and genetic interaction between the genotype and environment.

In general, according to the results of the analysis, we can conclude that, firstly, the manifestation of the QTLs identified in a regulated agroecosystem may or may not depend on environmental conditions, but the estimated quantitative traits interact and correlate with each other; second, more than one QTL can exist in one chromosome locus, determining two or more traits, forming blocks of evolutionarily coadapted genes; and, thirdly, the results obtained in this study can be used in the study of physiological and genetic mechanisms of the realization of the studied traits and for carrying out marker-assisted selection in wheat, as well as for the purposeful creation of lines and varieties suitable for their use in the system of high-precision agriculture with the purpose of increasing the economic and environmental efficiency of the latter.

\section{Bibliography}

1. ЖУЧЕНКО, А.А. Адаптивная система селекции растений (эколого-генетические основы). В двух томах. М.: Изд-во РУДН. 2001. 780 с.

2. ЖУЧЕНКО, А.А. Мобилизация генетических ресурсов цветковых растений на основе их идентификации и систематизации. М., 2012. 584 с.

3. ЖУЧЕНКО, А.А. Адаптивное растениеводство (эколого-генетические основы). Теория и практика. В трех томах. М.: Изд-во Агрорус. 2009. 1104 с.

4. CHESNOKOV, YU.V., KANASH, E.V., MIRSKAYA, G.V., KOCHERINA, N.V., RUSAKOV, D.V., LOHWASSER, U., BÖRNER, A. QTL mapping of diffuse reflectance indices of leaves in hexaploid bread wheat (Triticum aestivum L.) // Russian Journal of Plant Physiology. 2019. V. 66, No. 1. P. 77-86

5. ЖУЧЕНКО, А.А. Генетика томатов. Кишинев: «Штиинца». 1973. 663 с.

6. ЖУЧЕНКО, А.А. Экологическая генетика культурных растений. Кишинев: «Штиинца». 1980. 588 с.

7. САНДУХАДЗЕ, Б.И., ЖУРАВЛЕВА, Е.В., КОЧЕТЫГОВ, Г.В. Озимая пшеница Нечерноземья в решении продовольственной безопасности Российской Федерации. М.: ООО «НИПКЦ Восход-А». 2011. 156 с.

8. ЯКУШЕВ, В.П. На пути к точному земледелию. СПб.: Издательство ПИЯФ РАН. 2002. 458 с.

9. ЯКУШЕВ, В.В. Точное земледелие: теория и практика. СПб.: ФГБНУ АФИ. 2016. 364 с. 